\title{
A remarkable sand-dwelling fish assemblage from central Amazonia, with comments on the evolution of psammophily in South American freshwater fishes
}

\author{
Jansen Zuanon*, Flávio A. Bockmann**, and Ivan Sazima***
}

We studied a specialised assemblage of sand-dwelling fish species from a streamlet in central Amazonia. The five sanddwelling species comprised $15.2 \%$ of the total number in the streamlet (33 species). Two of the sand-dwellers are daytime foragers, Characidium cf. pteroides (Crenuchidae) and Stauroglanis gouldingi (Trichomycteridae), whereas three ones are night-time foragers, Gymnorhamphichthys rondoni (Rhamphichthyidae), "Imparfinis" pristos and Mastiglanis asopos (Heptapteridae). With the exception of $C$. cf. pteroides, the remainder species bury in the sand during their resting period. All five species bear a cryptic, sand-colour pattern, and some are translucent, traits which we regard as advantageous both for evasion from predators and for approaching prey (for the daytime foragers). All five species are microphagous carnivores and their foraging tactics range from generalised sit-and-wait (C. cf. pteroides) to active searching for interstitial prey (G. rondoni). A unique "drift-trap" system made up by the extended barbels and filamentous first pectoral-fin rays is employed by $M$. asopos. We regard the small size and low number of vertebrae (which is functionally expressed by fast displacements in the sand) as additional features advantageous to explore the sand habitat, allowing diving quickly in the substrate to evade predators and to forage for small prey in sand interstices or plant debris. The relationship between morphological and behavioural characters suited to life in sandy substrates is examined under the perspective of the current phylogenies for each group of psammophilous fishes here studied. The mapping of these characters demonstrates that not all of them evolved specifically for strict psammophily. Instead, some of them may represent the final step of a transformation series or synapomorphies of higher hierarchical levels. Several characters linked to psammophily, such as small body, large eyes, and scarce pigmentation are probably paedomorphic traits. We consider that the little variable specific composition of fish sand-dwelling assemblages and the wide (although patchy) geographical distribution of their species in the Amazon are due to the widespread occurrence and low complexity of this specialised habitat. The pre-existence of benthic habits, small size, and the broad distribution of rivers with sandy beds, mainly in the Amazon and Orinoco basins, possibly played a determinant role in the origin and diversification of psammophilous assemblages among freshwater fishes in South America.

Estudamos uma comunidade especializada de espécies de peixes psamófilos de um igarapé na Amazônia central. As cinco espécies psamófilas correspondem a $15.2 \%$ do número total estimado de espécies do igarapé (33 espécies). Duas das espécies psamófilas são forrageadores diurnos, Characidium cf. pteroides (Crenuchidae) e Stauroglanis gouldingi (Trichomycteridae), ao passo que três são forrageadores noturnos, Gymnorhamphichthys rondoni (Rhamphichthyidae), "Imparfinis" pristos e Mastiglanis asopos (Heptapteridae). Com exceção de C. cf. pteroides, as demais espécies ficam enterradas na areia durante seus períodos de repouso. Todas as cinco espécies apresentam padrão de colorido críptico na areia e algumas são translúcidas, características consideradas vantajosas tanto para evasão de predadores como para aproximação às presas (no caso dos forrageadores diurnos). Todas as espécies são carnívoras micrófagas e suas táticas de forrageamento variam de tocaia e espreita (C. cf. pteroides) a procura ativa de presas intersticiais (G. rondoni). Uma tática peculiar de caça ("armadilha-dederiva"), com uso de barbilhões estendidos e primeiros raios da nadadeira peitoral filamentosos, é empregada por M. asopos. Consideramos que o tamanho pequeno e o baixo número de vértebras (funcionalmente expresso por deslocamentos rápidos) são caracteres adicionais vantajosos para explorar o hábitat arenoso, permitindo o enterramento rápido na areia para evadir dos

\footnotetext{
* CPBA, Caixa Postal 478, INPA-Instituto Nacional de Pesquisas da Amazônia, 69083-970 Manaus, Amazonas, Brazil. e-mail: zuanon@inpa.gov.br

** Laboratório de Ictiologia de Ribeirão Preto, Departamento de Biologia, FFCLRP, Universidade de São Paulo, Av. dos Bandeirantes 3900 , 14040-901 Ribeirão Preto, São Paulo, Brazil. e-mail: fabockmann@ffclrp.usp.br

*** Departamento de Zoologia and Museu de História Natural, Caixa Postal 6109, Universidade Estadual de Campinas, 13083-970 Campinas, São Paulo, Brazil. e-mail: isazima@unicamp.br
} 
predadores ou capturar as pequenas presas nos interstícios arenosos ou restos vegetais. As relações entre os caracteres morfológicos e comportamentais adequados à vida em substrato arenoso são analisadas sob a perspectiva das filogenias de cada grupo de peixes psamófilos aqui estudados. O mapeamento destes caracteres demonstra que nem todos evoluíram especificamente para a psamofilia estrita. Ao contrário, alguns podem representar o estágio final de uma série de transformação ou sinapomorfias de níveis hierárquicos mais elevados. Vários caracteres relacionados à psamofilia, como corpo pequeno, olhos grandes, pigmentação escassa, são provavelmente atributos pedomórficos. Consideramos que a composição específica pouco variável das comunidades psamófilas e a distribuição geográfica ampla de suas espécies (embora pontual) são devidas à estabilidade e à baixa complexidade deste hábitat especializado. A pré-existência de hábitos bentônicos, pequeno tamanho e a ampla distribuição de rios com leitos arenosos, principalmente nas bacias dos rios Amazonas e Orenoco, possivelmente tiveram um papel preponderante na origem e diversificação das assembléias de peixes psamófilos na ictiofauna de água doce da América do Sul.

Key words: forest streams, fish diversity, phylogeny, feeding behaviour, drift-trap net.

\section{Introduction}

Fishes are able to dwell under the most variable and stressing habitat conditions, from hot desert springs to abyssal trenches (Helfman et al., 1997). These extremes apart, however, there are several habitats whose particularities are related to diverse specialised fish assemblages. Among these, intertidal fish assemblages are the most studied from the ecological and/or natural history views (review in Horn et al., 1999), along with torrential waters and rapids (e.g., Roberts \& Stewart, 1976; Casatti \& Castro, 1998). On the other hand, sand bottom fish assemblages, both marine and freshwater, are among the least studied. This seems paradoxical at a first sight, as sand bottom habitats are widespread and structurally simple, which may lead to a false view that sand-dwelling fish assemblages are relatively unspecialised, simple and/or uninteresting. However, a study of a near-shore sand community in the Pacific off California (Hobson \& Chess, 1986) revealed a rich and varied fish assemblage with remarkable features suited to this particular habitat. Nevertheless, we are unaware of ecological or natural history studies focused on freshwater sand-bottom fish assemblages.

We present here an observational study on a psammophilous (sand-dwelling) fish assemblage from a central Amazonia stream. Based on morphological and behavioural features recorded by Hobson \& Chess (1986) for a marine sand-dwelling assemblage, we hypothesised that the psammophilous fish species of the streamlet assemblage would present some or all of the following three characters: cryptic colours or behaviour (to evade visually oriented predators and approach preys), diverse foraging tactics (to lessen food overlap in a plain environment) and a sit-and-wait tactic for diurnally foraging species (to not disrupt their cryptic features). A detailed study on the natural history of Stauroglanis gouldingi de Pinna, a trichomycterid catfish from this psammophilous assemblage, was presented previously (Zuanon \& Sazima, 2004) and support the above mentioned hypotheses but one, as this fish searches actively for its prey at daytime. In addition to the field study, we examined the morphological features of each species which we regarded as related to a sand-dwelling habit under a phylogenetic perspective in order to examine whether they might have evolved in direct association with a psammophilous life or whether they represent synapomorphies of higher hierarchical levels instead. Further, we discuss the plausible origin and diversification of strict psammophily of freshwater fishes in South America.

\section{Material and Methods}

Field study was conducted in an unnamed clear-water igarapé (a local name for a forest streamlet or stream) tributary of the Rio Cuieiras in the Rio Negro drainage in central Amazonia, Brazil. The study site is described and illustrated in Zuanon \& Sazima (2004). Underwater observations were conducted in February and March 2001, and April 2002 (wet season), as well as October 2001, August 2002, 2003, and July 2004 (dry season), totalling 19 fieldwork days. Fish behaviour was observed directly, photographed, and video-taped during daytime as well as night time in 39 underwater sessions by snorkelling (Sabino \& Zuanon, 1998; Zuanon \& Sazima, 2004) and 12 sessions above water. Focal animal and all occurrences samplings (Lehner, 1979) were used throughout the study, totalling $41 \mathrm{~h}$ of behavioural records in situ. Subdued torchlight was used for night time observations. On two occasions during the dry and wet seasons a $20 \mathrm{~m}$ streamlet stretch was blocked with seines and all sand-dwelling species were removed with use of hand nets and dip nets, disturbing the sandy substrate, and the total catch was counted for proportion of each species. Several specimens were measured, dissected, and examined under stereomicroscope for gut contents and presence of mature oocytes. Standard length (SL) is used throughout unless indicated otherwise. Food items were identified to major categories and their importance in the diet was assessed by frequency of occurrence according to Hyslop (1980). Osteological examinations were made on cleared and double-stained specimens following Taylor \& Van Dyke (1985) procedures. All comparative heptapterids are listed in Bockmann (1998). Voucher specimens are in the fish collections of Instituto Nacional de Pesquisas da Amazônia (INPA 20074, 20081, 20099-20101), Laboratório de Ictiologia de Ribeirão Preto, Universidade de São Paulo (LIRP 5286-5290), and Museu de História Natural da Universidade Estadual de Campinas (ZUEC 5925-5927, 5929, 5932-5934). 
The interpretation on the origin of the morphological and behavioural characters associated with life on sandy bottoms was made under the light of currently accepted cladistic hypotheses of relationships for each group studied (Crenuchidae - Buckup, 1993a; Gymnotiformes and its family Rhamphichthyidae - Albert, 2001; Trichomycteridae and its subfamilies Glanapteryginae and Sarcoglanidinae -de Pinna, 1998; Heptapteridae - Ferraris, 1988; Bockmann, 1998; Bockmann $\&$ Ferraris, 2005). The citation of generic epithets between inverted commas through the text means that the generic allocation of the respective species is currently uncertain. The best course of action would be to incorporate these characters in data matrices so that they could interact with the whole data sets. However, to carry out a complete phylogenetic reanalyses of each group comprising psammophilous fishes is beyond the scope of this paper (moreover, a complete survey of the behavioural characters for the whole terminals of each group is currently unavailable). The approach here adopted was to map these features in the known phylogenies (mostly built on the basis of morphological data) and, on occasions, to point out their potential uses to enlighten new hypotheses. The phylogenies are presented in the resolution pertinent to the discussion.

\section{Results}

Species composition. We recorded five strictly sand-dwelling fish species in the streamlet: Characidium cf. pteroides Eigenmann (Crenuchidae), "Imparfinis" pristos Mees \& Cala and Mastiglanis asopos Bockmann (Heptapteridae), Stauroglanis gouldingi (Trichomycteridae), and Gymnorhamphichthys rondoni Miranda-Ribeiro (Rhamphichthyidae). The size range for observed individuals was (standard length-SL in mm): C. cf. pteroides (22.1-32.1), "I." pristos (23.1-27.2), M. asopos (37.1-63.7), S. gouldingi (19.1-26.5), and G. rondoni (170-228 total length-TL). The most common psammophilous species was $S$. gouldingi ( $40.7 \%$ of the total number of collected specimens), followed by $C$. cf. pteroides (24.4\%), $M$. asopos (18.6\%), "I." pristos (9.3\%), and G. rondoni (6.9\%). The total number of fish species recorded at the study site was 33 (1276 collected specimens), and thus the sand-dwellers contribute with $15.2 \%$ of the local species richness and $6.7 \%$ of the collected specimens.

Day and night time distribution within the habitat. Strictly diurnal foraging activity was recorded for Stauroglanis gouldingi and Characidium cf. pteroides, the former restricted to patches of loose sand where water flow forms small ephemeral ridges and grooves in the streamlet channel (see Zuanon \& Sazima, 2004), and C. cf. pteroides on both loose and more consolidated sand bottom, generally in shallower portions close to the bank (Fig. 1a). Gymnorhamphichthys rondoni (Fig. 1b), Mastiglanis asopos (Fig. 2), and "Imparfinis" pristos (Fig. 3) foraged only at night, the latter on the shallow portions near the gently sloping margin and the former in the channel. Mastiglanis asopos poised in the streamlet channel
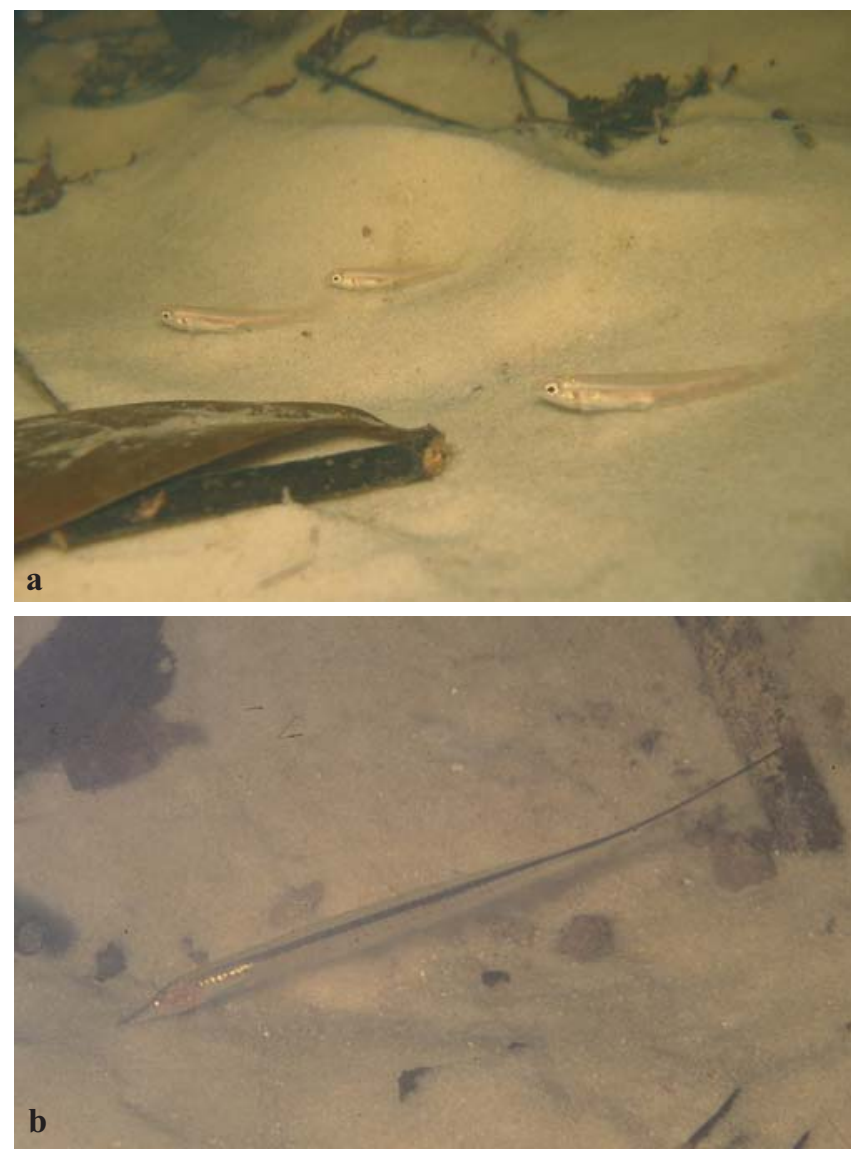

Fig. 1. Two species indicative of the morphological and behavioural variation found among the sand-dwelling fish assemblage in an Amazonian streamlet: a, the diurnally active Characidium cf. pteroides in its characteristic sit-and-wait posture while foraging for bottom-dwelling prey; $\mathbf{b}$, the nocturnally active Gymnorhamphichthys rondoni in its typical headdown posture while actively searching for interstitial prey.

while foraging (Fig. 2). The nocturnally active G. rondoni, "I." pristos, and M. asopos spent the daytime buried in the superficial portion of the sand. A few small individuals of $M$. asopos foraged at morning and buried in the sand after midday. When the sand was disturbed (e.g., by walking on the bottom), M. asopos emerged for a short time burying afterwards. The diurnally active $S$. goulding $i$ spent the night time buried in the sand (Zuanon \& Sazima, 2004), whereas the also diurnal $C$. cf. pteroides rested at night in the shallows or among plant debris close to the bank.

Foraging and agonistic behaviour. Sit-and-wait foraging tactic was employed by three species: Characidium cf. pteroides at daytime, and "Imparfinis" pristos and Mastiglanis asopos at night time. Characidium cf. pteroides poised on the bottom supported by its pectoral and pelvic fins (sometimes the caudal fin was also used), its fore body above the substrate while searching visually for prey and darting forwards to grab it, gradually changing its hunting spot. A less common tactic 


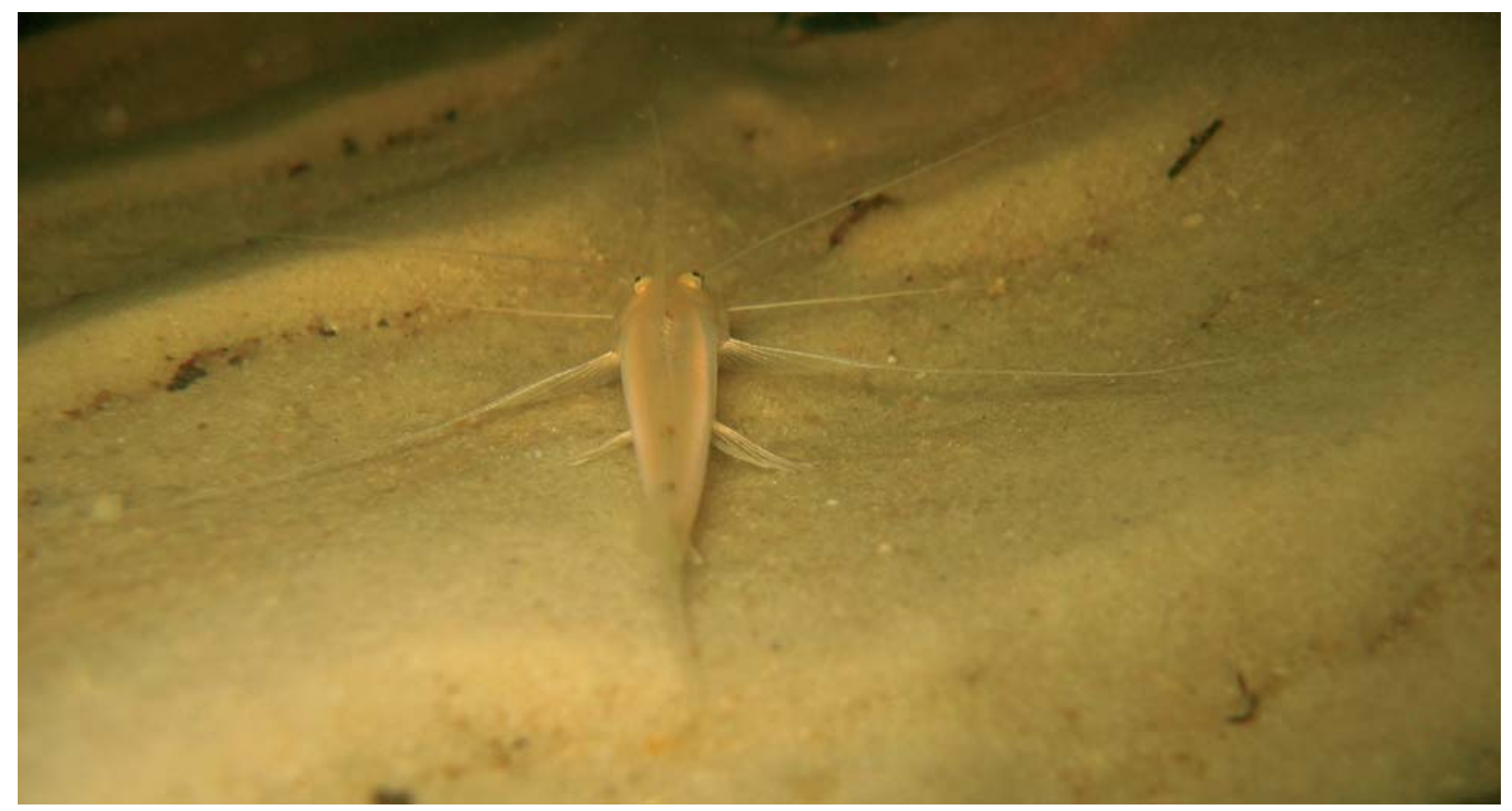

Fig. 2. The sit-and-wait foraging posture of Mastiglanis asopos in posterior view. Note very long barbels and filamentous rays of pectoral fins spread in a drift trap-like device, as well as the alignment of mentonian barbels and pectoral filaments.

was to catch drifting prey close to the bottom ("bottom driftfeeding").

Mastiglanis asopos employed a remarkable sit-and-wait foraging tactic: poised on the bottom and supported by a tripod formed by its pelvic and anal fins, the fish spread both the very long barbels and the filamentous dorsal and pectoral-fin rays, thus forming a kind of "drift-trap" (Fig. 2) and intercepted and lunged at drifting food particles. When lunging sideways or forwards for a short distance, the catfish resumed its position on the previous hunting spot. Large drifting debris were avoided by the fish moving out of the way, whereas smaller debris entangled on the barbels or the pectoral filaments was ridden off by fin closing movements (the spread pectoral fins may also act as a water-flow deflector helping the fish to maintain its position in the channel current). "Imparfinis" pristos was the most elusive fish, and employed a tactic intermediate to those recorded both for $M$. asopos and Characidium cf. pteroides. It spread its pelvic fins close against the bottom forming a tripod similar to that of $M$. asopos and lunged forwards and sideways, making short displacement similar to those of $C$. cf. pteroides, but resumed its former hunting spot afterwards. The sit-and-wait foragers changed their hunting spot from time to time, especially C. cf. pteroides.

Active searching was employed by Stauroglanis gouldingi at daytime, which foraged only along sand grooves and scanned the bottom back and forth, lunging at its prey (see Zuanon \& Sazima, 2004). The night time active Gymnorhamphichthys rondoni searched for interstitial prey and buried its snout in the sand while hovering head-down (Fig. 1b).

One instance of agonistic behaviour was recorded between two similarly-sized individuals of Mastiglanis asopos: one of them was foraging when another approached and the two fish became aligned. The newcomer then tried to displace the other individual making lateral movements of the fore body, the two fish moving this way side by side, touching each other with their barbels and pectoral fins. The interaction ceased when there was no more physical contact between the two still aligned fish.

Major food types. Bottom-dwelling, aquatic immature insects (mainly chironomid and ceratopogonid larvae) were the staple food for all five psammophilous fishes (Table 1). Coleopteran larvae (mainly Elmidae) were an important food item for Gymnorhamphichthys rondoni, whereas small trichopteran lar-

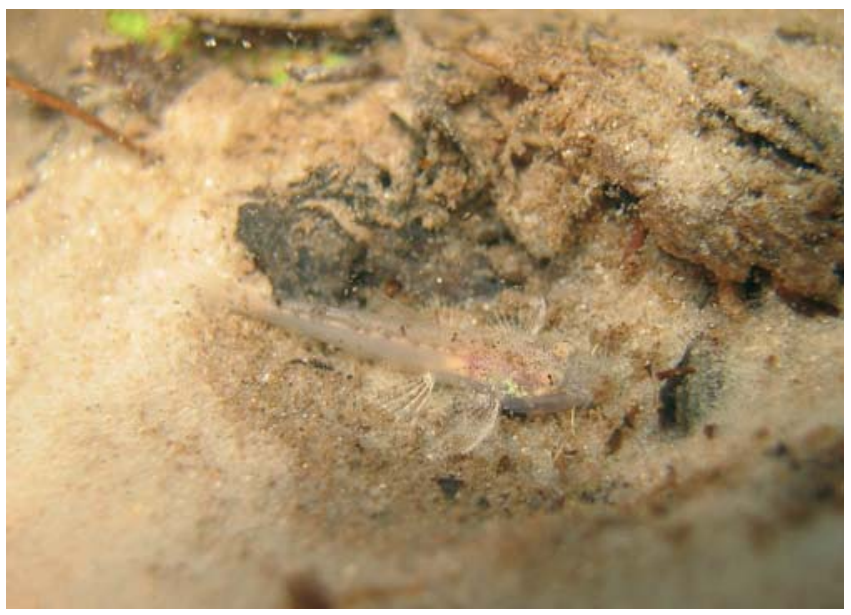

Fig. 3. The sit-and-wait foraging posture of "Imparfinis" pristos in dorsal view. Note translucent body and commashaped pupil. 


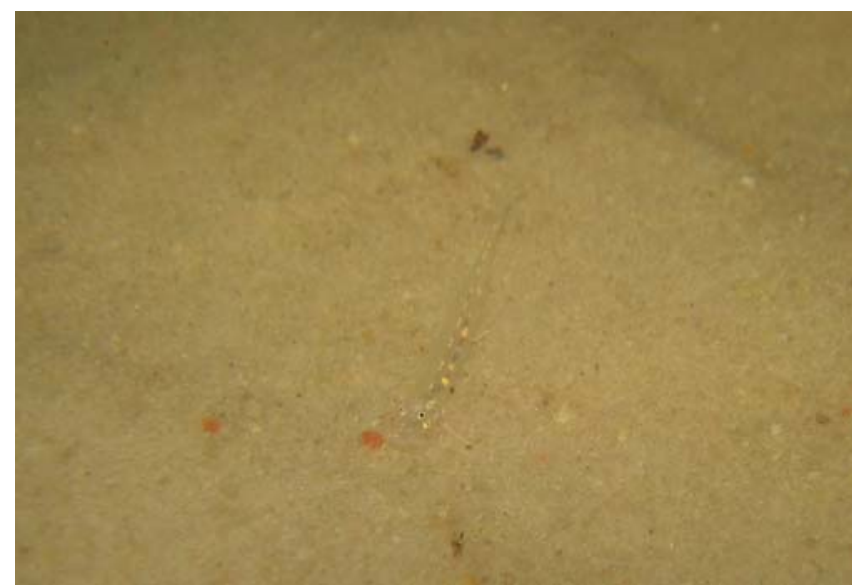

Fig. 4. The minute and translucent Stauroglanis gouldingi (not preserved) poised on the sandy stream bottom.

vae (ingested with the sand cases) and ephemeropterans constituted a considerable portion of the gut contents of Mastiglanis asopos. Crustaceans were poorly represented in the stomachs of the five species and a dragonfly nymph occurred in a single G. rondoni specimen. Sand grains were found in the guts of all species but fine sediment occurred only in the stomach of G. rondoni and "Imparfinis" pristos.

Reproduction. Most specimens collected during the dry season (five Characidium cf. pteroides, eight Gymnorhamphichthys rondoni, eight Mastiglanis asopos, and seven "Imparfinis" pristos) had no mature eggs. On the other hand, four of the five examined specimens of $C$. cf. pteroides (collected during the early rainy season) were ripe females. All examined specimens of $M$. asopos (three females and three males) and "I." pristos (four females) also had mature gonads during February-March. Females with mature or maturing oocytes were also recorded for Stauroglanis gouldingi in the Amazonian wet season from December to May (see Zuanon \& Sazima, 2004).

\section{Discussion}

Species composition and systematic framework. All recorded psammophilous species are Ostariophysi: one characiform (Characidium cf.pteroides), one gymnotiform (Gymnorhamphichthys rondoni), and three siluriforms ("Imparfinis" pristos, Mastiglanis asopos, and Stauroglanis gouldingi). The dominant fishes in the psammophilous assemblages are catfishes, which may be explained by their bottom dwelling habits (Lowe-McConnell, 1987; de Pinna, 1998). Although Characiformes is one of the dominant groups in Neotropical streams (e.g., Lowe-McConnell, 1991; Casatti \& Castro, 1998; Sabino \& Zuanon, 1998), their small representation in the sand-dwelling assemblage relates to the fact that very few characin species are tied to the bottom, a trait found mostly within Characidiinae (Buckup, 2003) and Parodontidae (e.g., Sazima, 1980). Similarly, very few species of Gymnotiformes dwell in sandy habitats, the family Rhamphichthyidae being one exception (Schwassmann, 1976; Ferraris, 2003).

The characiform Characidium cf. pteroides belongs to a group which includes C. pellucidum Eigenmann, C. pteroides Eigenmann, C. steindachneri Cope, and at least one undescribed species, all part of an apical clade of the Crenuchidae (Buckup, 1993a). The trichomycterid Stauroglanis gouldingi is within the Sarcoglanidinae, the sister group of Glanapteryginae (de Pinna, 1998). The two psammophilous heptapterids "Imparfinis" pristos and Mastiglanis asopos are members of the Nemuroglanis sub-clade (Ferraris, 1988; Bockmann, 1994). They are part of a well-corroborated monophyletic group within this sub-clade which also includes "Cetopsorhamdia" molinae Miles, "C." phantasia Stewart, "C." orinoco Schultz, "Nannorhamdia" stictonotus Fowler, and species of Horiomyzon Stewart, Imparfinis Eigenmann

Table 1. Frequency of occurrence of major food types in the diet of five sand-dwelling fish species from a forest streamlet in central Amazonia during dry season. Numbers in parentheses are size range of examined specimens (standard length in $\mathrm{mm}$; total length for G. rondoni).

\begin{tabular}{|c|c|c|c|c|c|}
\hline \multicolumn{6}{|l|}{ Food items } \\
\hline & C. cf. pteroides & G. rondoni & "I." pristos & M. asopos & S. gouldingi \\
\hline & $\begin{array}{c}\mathrm{N}=? \\
(27.0-31.56)\end{array}$ & $\begin{array}{c}\mathrm{N}=7 \\
(180.0-225.0)\end{array}$ & $\begin{array}{c}\mathrm{N}=7 \\
(24.0-28.9)\end{array}$ & $\begin{array}{c}\mathrm{N}=7 \\
(38.0-46.0)\end{array}$ & $\begin{array}{c}N=13 \\
(19.1-26.5)\end{array}$ \\
\hline Insecta & 100.0 & 100.0 & 100.0 & 100.0 & 100.0 \\
\hline Ceratopogonidae (larvae) & 00.0 & 83.3 & 33.3 & 50.0 & 38.5 \\
\hline Chironomidae (larvae) & 100.0 & 100.0 & 100.0 & 100.0 & 84.6 \\
\hline Diptera (pupae) & 00.0 & 16.7 & 00.0 & 00.0 & 00.0 \\
\hline Coleoptera (adults) & 00.0 & 00.0 & 00.0 & 33.3 & 00.0 \\
\hline Odonata (Gomphidae larvae) & 00.0 & 16.7 & 00.0 & 00.0 & 00.0 \\
\hline Ephemeroptera (larvae) & 16.7 & 00.0 & 16.7 & 42.9 & 7.7 \\
\hline Trichoptera (larvae) & 16.7 & 00.0 & 16.7 & 50.0 & 00.0 \\
\hline Crustacea & 33.3 & 14.3 & 00.0 & 00.0 & 38.5 \\
\hline Conchostraca & 00.0 & 00.0 & 00.0 & 00.0 & 7.7 \\
\hline Ostracoda & 00.0 & 16.7 & 00.0 & 00.0 & 7.7 \\
\hline Copepoda (Harpacticoidea) & 33.3 & 00.0 & 00.0 & 00.0 & 15.4 \\
\hline Others (fish and insect eggs, plant fragments) & 16.7 & 14.3 & 33.3 & 33.3 & 3.1 \\
\hline
\end{tabular}


\& Norris, and Nemuroglanis Eigenmann (Bockmann, 1998; Bockmann \& Ferraris, 2005). Within this monophyletic group, here named the Imparfinis clade, "I." pristos and M. asopos are distantly related taxa: the former is the sister group of Horiomyzon, whereas the latter is closely related to " $C$." phantasia and "N." stictonotus, which form an apical lineage nested in this clade (Bockmann, 1998).

Distribution, activity period and foraging behaviour. Most catfishes are nocturnally active (e.g., Lowe-McConnell, 1987; de Pinna, 1998), although juveniles of several species tend to be active also at daytime (our pers. obs.). Daytime foraging activity as displayed by Stauroglanis gouldingi is uncommon among Trichomycteridae (de Pinna, 1998), but very little is known on the habits of the miniature and cryptobiotic species within the family (see Zuanon \& Sazima, 2004). The supposed daytime activity and the swimming in rocky pools reported for Mastiglanis asopos by E. P. Caramaschi (Bockmann, 1994) likely relates to fish disturbed while resting.

The position of Mastiglanis asopos in the streamlet channel is related to its foraging behaviour, as more particles would be carried through the portion with stronger water flow. Similar situation is described for Stauroglanis gouldingi, which also depends on food carried and accumulated in its ridgegroove microhabitat (Zuanon \& Sazima, 2004). On the other hand, Characidium cf. pteroides and "Imparfinis" pristos are less specialised sit-and-wait foragers and this may explain their position in shallower and quieter parts of the streamlet. Unfortunately, the scarcity of data on foraging behaviour of these three fish groups prevents the assessment of the polarity and distribution of these character states.

Among the studied sand-dwellers, a most striking and unexpected foraging behaviour is that displayed by Mastiglanis asopos. The "drift-trap system" formed by its spread barbels and first pectoral rays seems unique among freshwater fishes recorded so far. We suppose that the uncommon feeding tactic of $M$. asopos may have arisen as a novel use for a common trait in catfishes, viz. spread barbels when actively foraging (see figures in Burgess, 1989). Moving with spread whiskers to adopt a sit-and-wait tactic along with the spreading is a relatively simple behavioural step from the evolutionary viewpoint, and the very long first pectoral fin-rays add a more favourable condition to this step. A stationary bottom-drift feeding tactic, with barbels spread against the water flow was recorded for Pimelodella sp. in South-eastern Brazil (JZ, pers. obs.), and may be regarded as an intermediary step towards the "drift-trap" feeding of $M$. asopos. Two independent morphological characters favour this foraging behaviour of $M$. asopos: the very long maxillary barbels and first pectoral-fin ray. Despite of being unusual, the long maxillary barbel of M. asopos is not exclusive, but an autapomorphy for the Imparfinis clade (reversed in "Imparfinis" pristos) (Bockmann, 1998). Well-developed dorsal, pectoral, and pelvic fins are common among this clade (Bockmann, 1998). In contrast, "I." pristos has small dorsal, pectoral, and pelvic fins, a presumably plesiomorphic state
(Bockmann, 1998). Within the Imparfinis clade, the first pectoral and dorsal-fin rays prolonged as filaments are also seen, although in attenuated states, in "Cetopsorhamdia" phantasia (Stewart, 1985; Bockmann, 1998) and "Nannorhamdia" stictonotus (Bockmann, 1998), the closest relatives of Mastiglanis, and in I. nemacheir Eigenmann \& Fisher (Mees \& Cala, 1989). We suggest that the heptapterids "C." phantasia, I. nemacheir, and "N." stictonotus are strong candidates to forage in a way similar to that here described for M. asopos, notwithstanding a few differences in colour and/or shape (e.g., Fowler, 1940; Stewart, 1985).

The very unusual feeding mode of Mastiglanis asopos finds a counterpart in the tactic employed by bathydemersal tripodfishes, species of Bathypterois Günther (Ipnopidae), which also spread their very long and filamentous pectoral fin-rays while poised on the bottom (see figures in Bernard, 1958; Froese \& Pauly, 2005). These fishes face the current while in this posture, and feed on benthopelagic plankton, and squids (Sulak, 1984; Froese \& Pauly, 2005).

The sand probing employed by Gymnorhamphichthys rondoni is similar to that recorded for the closely related genus Rhamphichthys Müller \& Troschel (Schwassmann, 1976) and the long snout is very suitable for this task. The buried prey of knife fishes is pinpointed by electrolocation (Schwassmann, 1976); the foraging behaviour varies between species and/or families and is correlated with body shape and electric organ discharge type (Nanjappa et al., 2000).

Avoidance behaviour following a very quick bodily contact is recorded for foraging individuals of Stauroglanis gouldingi, probably related to their searching for food in the dynamic ridge-and-groove system (Zuanon \& Sazima, 2004). The strict use of this microhabitat for foraging by $S$. gouldingi is commented upon by Zuanon \& Sazima (2004), and seems unique among trichomycterid catfishes. The agonistic behaviour here recorded for Mastiglanis asopos is probably related to maintenance of a short-term feeding space rather to a long-term territoriality. As the water flow and the sandy bottom are changing constantly, more intense aggressive interactions such as mutual chasing recorded for most siluriforms (Trajano, 1990) would be improbable.

Diet and food resource use. The diet of all five sand dwelling fish species was largely based on aquatic immature insects and was roughly similar among the examined species. The main differences seem to be related to feeding tactic and microhabitat exploited by each species during foraging.

The nocturnal use of marginal, sediment loaded areas by "I." pristos is evidenced by the presence of fine sediments in its gut contents, as well as by the occurrence of a few mites in the diet. Food items similar to that of the above mentioned species are taken by $C$. cf. pteroides at the same marginal areas but during daytime, which may be regarded as a temporal sharing of food resources.

The ingestion of food collected with use of a very specialized "drift-trap" by M. asopos allows a varied diet which includes large chironomid larvae and small adult beetles, un- 
recorded in the gut contents of the other sand dwelling species. Stauroglanis gouldingi feeds on small food items in a microhabitat apparently not exploited by the other sand dwellers, which may contribute to reduce diet overlapping between the fish species (e.g. Greenberg, 1991; Sabino \& Zuanon, 1998).

The large numbers of small chironomid and ceratopogonid larvae are caught by G. rondoni deeper in the sand by probing repeatedly the substrate with its long snout while moving along the streamlet channel. The occurrence of a gomphid dragonfly nymph (which buries deep in the sand) in its gut contents indicates an additional type of food partitioning based on the depth of the substrate exploited by the sand dwelling species. Thus, temporal segregation and differential use of foraging grounds between the psammophilous fishes seem to allow some degree of food partitioning, perhaps lessening competition in a patchy environment (e.g. Hori, 1983; Greenberg, 1991; Sabino \& Zuanon, 1998).

Reproduction. The occurrence of ripe females of Stauroglanis gouldingi (see Zuanon \& Sazima, 2004), Characidium cf. pteroides, Mastiglanis asopos, and "Imparfinis" pristos exclusively during the rainy season indicates a strongly seasonal reproductive pattern for the sand dwelling fish assemblage. A seasonal, monomodal spawning activity is a widespread strategy among Amazonian fish species in distinct aquatic environments and seems related mainly to dispersion of eggs and larvae (Lowe-McConnell, 1987). Peaks in the abundance of food and shelter are also supposed to be important factors leading to this generalized pattern of reproduction among the regional fish fauna. The short duration (up to some days or hours) of floods in the small forest streams does not allow a predictable increase in habitat availability for colonization by the fish larvae, and probably is not an important selective pressure leading to a strongly seasonal reproduction among these species. Also, a lengthy drifting of eggs and larvae may be a risky strategy for these species that depend on the availability of sand patches for colonization. In this sense, seasonal reproduction in sand-dwelling fish assemblages may be related especially to peaks in food availability (mostly small aquatic insect larvae) for the juvenile fish, although phylogenetic constraints cannot be excluded.

Morphological characteristics related to the life on exposed sand patches. We comment here on the most remarkable morphological features of the members of the psammophilous assemblage (most of them thought to be related to life in and on the sand), attempting to map their origin in each lineage in which they are presently allocated.

Cryptic colour. Most species of Crenuchidae, Heptapteridae, Rhamphichthyidae, and Trichomycteridae, fish groups which include the five species studied here, have dark overall coloration. A series of morphological and behavioural traits are needed to suit a very light background, like shallow silica sand patches. Light coloured and/or translucent bodies are typical of fish species dwelling on open, sandy bottoms (e.g.
Hobson \& Chess, 1986; Helfman et al., 1997), and these characters are probably paedomorphic.

The psammophilous heptapterids are characterized by translucent body in life (white when dead). The non- or weakdevelopment of ground pigmentation in non-troglobitic heptapterids took place at least twice within the Imparfinis clade: one in the clade Horiomyzon + "Imparfinis" pristos, and one in the clade "Nannorhamdia" stictonotus + ("Cetopsorhamdia" phantasia + Mastiglanis asopos) (reversed in "C." phantasia) (Bockmann, 1998). The fading or completely absence of the dorsal transverse bars, which favours camouflage on sandy bottoms, may be regarded as a synapomorphy for the Imparfinis clade, with a reversion in the genus Imparfinis (s. s.). Similarly, the colour pattern displayed by the species of the clade that includes Characidium cf. pteroides represents the less extreme condition of the widespread dark vertical bars among Characidiinae (Buckup, 1993a). The potential disadvantages of the somewhat darker colour pattern of Gymnorhamphichthys rondoni are probably counterbalanced by its nocturnal habits and burying behaviour during the day (see below).

Small body size. Small size is a common trait for psammophilous fishes; the only exception among the species studied here is the gymnotiform Gymnorhamphichthys rondoni. Small size is also likely a paedomorphic character. The characin Characidium cf. pteroides reaches $32.1 \mathrm{~mm}$ SL, but small size is a generalised trend in crenuchid characins, which rarely surpass $8 \mathrm{~cm}$ SL ( $c f$. Buckup, 2003). The trichomycterid Stauroglanis gouldingi reaches $27 \mathrm{~mm}$ SL (de Pinna \& Wosiacki, 2003). Miniaturization is regarded by Costa \& Bockmann (1994a) as a synapomorphy uniting the subfamilies Glanapteryginae and Sarcoglanidinae. However, size reduction has a wider distribution among the members of the clade TSVSG, which includes the subfamilies Tridentinae, Stegophilinae, Vandelliinae, Sarcoglanidinae, and Glanapteryginae ( $c f$. de Pinna, 1998) and possibly is an additional synapomorphy for this group. The maximum length recorded for the heptapterids "Imparfinis" pristos and Mastiglanis asopos is 38 and $66 \mathrm{~mm} \mathrm{SL}$, respectively (Bockmann \& Guazzelli, 2003). With few exceptions, the members of the Imparfinis clade usually do not exceed $100 \mathrm{~mm} \mathrm{SL}$ (Bockmann \& Guazzelli, 2003), this condition being regarded as derived, and may prove to be synapomorphic for this group.

Low number of vertebrae. The ability to perform fast movements is a valuable trait to fishes which live in highly visible backgrounds, such as silica sand bottoms. A small number of vertebrae (here 43 vertebrae or fewer), and consequent shortbodied aspect, is likely related to fast movements with limited bending. On the other hand, the high number of vertebrae (here 45 vertebrae or more, usually over 50 ), and consequent elongate aspect, is usually related to greater skill for bending or undulating in confined spaces such as crevices of stony beds or in small spaces of a leaf litter microhabitat.

The characin Characidium cf. pteroides has a small num- 
ber of body vertebrae, within the range (30-36) recorded for members of the family Crenuchidae ( $c f$. Buckup, 1993b; Buckup $\&$ Reis, 1997). However, small number of vertebrae is a conservative feature among Characiformes.

The sarcoglanidine $S$. gouldingi has 40 vertebrae (de Pinna, 1989a), and all sarcoglanidines have 43 or fewer vertebrae (cf. Costa, 1994; Costa \& Bockmann, 1994a; Costa et al., 2004; de Pinna \& Starnes, 1990; de Pinna \& Winemiller, 2000). The number of vertebrae of Microcambeva Costa \& Bockmann, Stauroglanis, and Stenolicmus de Pinna \& Starnes, although low, probably is a plesiomorphic state whereas 39-43 vertebrae is a variation widespread in the basal trichomycterid outgroups (e.g. de Pinna, 1992; Bockmann \& Sazima, 2004). As expected, the psammophilous and fossorial glanapterygines Pygidianops Myers and Typhlobelus Myers have a high number of vertebrae (45 in the former and 60 in the latter - Baskin, 1973; Schaefer et al., 2005). However, these high counts are plausibly inherited from its nearest common ancestor, which likely lived in leaf litter, a habit retained by the most basal glanapterygines, Glanapteryx Myers and Listrura de Pinna (cf. de Pinna, 1989b; Landim \& Costa, 2002).

Both the studied psammophilous heptapterids have short and little segmented bodies. "Imparfinis" pristos and Mastiglanis asopos have 33 and 37-38 vertebrae, respectively (Bockmann, 1994, 1998). "Imparfinis" pristos and M. asopos were here recorded performing short but very fast and vigorous lateral displacements. Reduced vertebral counts are widespread throughout the remaining members of the Imparfinis clade, ranging 35-44 (cf. Bockmann, 1998; Bockmann \& Ferraris, 2005), and may be a further synapomorphy for the Imparfinis clade (Bockmann, 1998). As expected, an elongate body bearing a high number of vertebrae is a trend among heptapterids which live in confined spaces, such as Heptapterus Bleeker, which occupies rocky crevices (54-57 vertebrae), and Gladioglanis Ferraris \& Mago-Leccia, which dwells in leaf litter (45-51 vertebrae) (e.g. Lundberg et al., 1991; Bockmann, 1998; JZ, pers. obs.).

Large and dorsally placed eyes. Eyes large ( $20 \%$ or greater in HL) and dorsally placed are present in adults of the three catfishes and the characin, whereas they are small and lateral in the knifefish adults. The retention of large eyes in adults likely is paedomorphic inasmuch as fish juveniles tend to have relatively larger eyes than those of adults. Large eyes probably lead to a narrow interorbital region which, in turn, is probably related to their dorsal position ( $c f$. figures in Bockmann, 1994, 1998; de Pinna, 1989a).

The importance of visual orientation in the foraging of the trichomycterid Stauroglanis gouldingi, which is likely favoured by their dorsally positioned and large eyes, is pointed out by Zuanon \& Sazima (2004). This condition in S. gouldingi is likely derived, although a common trait in adult sarcoglanidines (de Pinna, 1989a; Costa \& Bockmann, 1994a). Eyes are small in Ammoglanis pulex Pinna \& Winemiller ( $c f$. de Pinna \& Winemiller, 2000) and Stenolicmus sarmientoi de Pinna \& Starnes ( $c f$. de Pinna \& Starnes, 1990), and very small or absent in the psammophilous and interstitial glanapterygines Pygidianops and Typhlobelus (Myers, 1944; Costa \& Bockmann, 1994b; Schaefer et al., 2005). Small or lacking eyes are usual among fishes that live in confined spaces with scarce or absent light, and thus this trait is not exclusively related to fossorial psammophily. These characters of Pygidianops and Typhlobelus likely are inherited from their nearest common ancestor, which probably lived in the confined spaces of leaf litter, a habit retained by the most basal glanapterygines, Glanapteryx and Listrura (cf. de Pinna, 1989b; Landim \& Costa, 2002; Schaefer et al., 2005).

Eyes are also large in the psammophilous heptapterids "Imparfinis" pristos and Mastiglanis asopos, whose diameters are 20.8-23.8\% in HL and 18.9-21.8\% in HL, respectively (Mees \& Cala, 1989; Bockmann, 1994). Large eyes appeared independently, as in "I." pristos they are an autapomorphy (Horiomyzon, its putative sister group, has minute eyes, see Stewart, 1986), and in M. asopos they are shared by a clade that also includes at least "Nannorhamdia" stictonotus and "Cetopsorhamdia" phantasia (Bockmann, 1998).

A comma-shaped pupil as seen in "Imparfinis" pristos and Mastiglanis asopos (see also figures in Le Bail et al., 2000, misidentified as Megalonema cf. platycephalum Eigenmann) likely favours life on a plain and well lit shallow bottom of silica sand. The remarkable pupil morphology of Mastiglanis asopos and "Imparfinis" pristos (Fig. 3) is regarded as independent acquisitions (Bockmann, 1998). However, the eyes of the psammophilous "Nannorhamdia" stictonotus, which is closely related to M. asopos, share the comma-like pupil ( $c f$. photograph in Kobayagawa, 1991, misidentified as Imparfinis minutus Lütken).

Burying and probing behaviours and head morphology. With the exception of the characin Characidium cf. pteroides, all other psammophilous species bury in the sand during their resting period. No characiform is known to bury in the sand, but this behaviour is to be expected among trichomycterids, heptapterids, and gymnotiforms, since most species within these groups are cryptobiotic fishes which use crevices, logs, and vegetation for shelter (Lowe-McConnell, 1987). Several species of diurnal sand-dwelling marine fishes, e.g., in the Labridae, Creediidae, and Gobiidae also rest at night buried in the sand (e.g., Hobson \& Chess, 1986; Cozzi \& Clark, 1995).

Acuminate snout and elongate body shape of the three catfish species here studied are well suited for their burying in the sand (Zuanon \& Sazima, 2004). However, the external resemblance of snout morphologies in Stauroglanis gouldingi, "Imparfinis" pristos, and Mastiglanis asopos results from different anatomical traits and sets of bones in each species. In S. gouldingi the pointed snout is probably autapomorphic and may be linked to the convex contour of the anterior cornua of the mesethmoid (cf. de Pinna, 1989a). This condition is also recorded for the sarcoglanidine Malacoglanis gelatinosus Myers \& Weitzman (Baskin, 1973; de Pinna, 1989a) but this fish have no an acuminate snout ( $c f$. Myers \& Weitzman, 1966). The psammophilous and fossorial 
glanapterygines Pygidianops and Typhlobelus have remarkable shovel-like snouts (Myers, 1944; Costa \& Bockmann, 1994b; Schaefer et al., 2005). In M. asopos the acuminate snout is mostly produced by an anterodorsally oriented shelflike process at the symphiseal region of the premaxilla and by the anterior cornua of the mesethmoid abruptly assuming a reversed direction at their mid-length, two autapomorphies for this species (Bockmann, 1994). "Imparfinis" pristos has a pointed snout resulting from the angled and narrow premaxillae and, probably, by their short anterior mesethmoid cornua, two autapomorphic features (Bockmann, 1998).

Elongation of the snout as seen in Gymnorhamphichthys rondoni likely evolved independently in Rhamphichthyidae and in at least three separates lineages of the family Apteronotidae, each time involving different sets of bones (Albert, 2001).

The thick and short maxillary barbel of Stauroglanis goulding $i$ is regarded as related to its burying habits (Zuanon \& Sazima, 2004). The maxillary barbel is short in "Imparfinis" pristos (Mees \& Cala, 1981), and very long in Mastiglanis asopos (Bockmann, 1994). The short barbel of "I." pristos, possibly an autapomorphy (Bockmann, 1998), may be favourable to its burying habits while the unusually long maxillary barbel of M. asopos is an essential part of the foraging "drift-trap system" (see above).

Distribution, biogeography, and origin of psammophily in South America. So-called rarity and endemism of sand-dwelling fishes, with most of their species known until recently from a few specimens and the type localities only (e.g., de Pinna, 1989a; Buckup, 1993a; Costa \& Bockmann, 1994a, b) result from collection biases. Scarcity of psammophilous fishes in museum collections is likely due to their small sizes, secretive and cryptic habits, and collecting efforts not focused on patchy sandy substrates through the river systems (de Pinna \& Wosiacki, 2003; Schaefer et al., 2005; our pers. obs.). In fact, most of these fishes are more broadly distributed and less rare than previously thought (de Pinna \& Wosiacki, 2003; Zuanon \& Sazima, 2004), as was predicted by Myers \& Weitzman (1966) and Costa \& Bockmann (1994b).

No comments upon the distribution of the crenuchid Characidium cf. pteroides may be made, as the taxonomy of this species and other psammophilous species of the genus (all known from the Amazon and Orinoco River basins of Brazil, Colombia, Ecuador, Guyana, Peru, and in drainages of Guyana region; see Buckup, 2003) needs a thorough revision.

The remaining psammophilous fishes here studied have noticeably broad distributions. The trichomycterid Stauroglanis gouldingi is described from two localities in the Rio Negro basin (de Pinna, 1989a), and a third locality is reported by Zuanon \& Sazima (2004). Although the heptapterid "Imparfinis" pristos is described from a small tributary of the Orinoco River in Colombia (Mees \& Cala, 1989), currently it is recorded along the Madeira, Negro, Orinoco, Purus, Xingu and Tapajós River basins in Brazil, Colombia, and Venezuela
(Bockmann \& Guazzelli, 2003; FAB \& JZ, pers. obs.). The specific epithet of Mastiglanis asopos was coined in reference to its broad distribution, mainly throughout the left side tributaries of the Amazon basin and the Capim River basin in Brazil (Bockmann, 1994). In fact, this catfish has further a wider distribution, in the right tributaries of the Amazon basin in Brazil, Orinoco basin of Venezuela, and drainages in Guyana (e.g., misidentified as Megalonema cf. platycephalum by Le Bail et al., 2000). The gymnotiform Gymnorhamphichthys rondoni is recorded from the Amazon, upper Paraná, Orinoco River basins of Brazil, Colombia, Paraguay, and Venezuela, and in coastal rivers in the Guyanas (Ferraris, 2003). However, there are several species similar to what we call here G. rondoni (Campos-da-Paz, 1997) and thus further distributional comments are of no use.

The following freshwater fish species from South America may doubtless be referred as strictly psammophilous. Four species of the crenuchid Characidium (C. pellucidum, $C$. pteroides, C. steindachneri, plus one undescribed - Buckup, 1993a); two species of the trichomycterid Ammoglanis Costa (A. diaphanus Costa and A. pulex), one of Malacoglanis Myers \& Weitzman (M. gelatinosus), four of Microcambeva (M. barbata Costa \& Bockmann and M. ribeirae Costa et al., 2004, plus two undescribed - Costa et al., 2004), three or four of Pygidianops (P. eigenmanni Myers, P. cuao Schaefer et $a l$. and $P$. magoi Schaefer et al., plus one undescribed - de Pinna \& Wosiacki, 2003; Schaefer et al., 2005), one of Sarcoglanis Myers \& Weitzman ( $S$. simplex Myers \& Weitzman), one of Stauroglanis (S. gouldingi), and four or five of Typhlobelus (T. macromycterus Costa \& Bockmann, T. ternetzi Myers, T. guacamaya Schaefer et al., plus one undescribed ; FAB \& JZ, pers. obs.); one species of the heptapterid "Imparfinis" "II." pristos), one of Mastiglanis Bockmann (M. asopos), one of "Nannorhamdia" ("N." stictonotus), one of the pimelodid Megalonema Eigenmann (M. psammium Schultz, 1944), four species of the gymnotiform Gymnorhamphichthys Ellis (G. hypostomus Ellis, G. petiti Géry \& Vu-TânTuê, G. rondoni, and G. rosamariae Schwassmann - Ferraris, 2003), one of Iracema Triques (I. caiana Triques), and eight species of Rhamphichthys [ $R$. apurensis Fernández-Yépez, $R$. atlanticus Triques, $R$. drepanium Triques, $R$. hahni (Meiken), $R$. lineatus Castelnau, $R$. longior Triques, $R$. marmoratus Castelnau, and $R$. rostratus (Linnaeus) - Ferraris, 2003].

We are unaware of studies on freshwater sand-dwelling fish assemblages other than that presented here. Myers \& Weitzman (1966) mentioned that Gymnorhamphichthys hypostomus inhabits a locality in Colombia where the psammophilous sarcoglanidine Malacoglanis gelatinosus was caught. Schaefer et al. (2005) also present information on collecting localities and habitats for species of Pygidianops and Typhlobelus. However, based on our experience in museum collections, there seems to be a low variation in species composition of sand-dwelling assemblages. These usually contain the sympatric heptapterids "Imparfinis" pristos and Mastiglanis asopos, one species of Sarcoglanidinae, one or 
two species of interstitial Glanapteryginae (Pygidianops and/ or Typhlobelus), one or two species of Vandelliinae (mostly Paracanthopoma Giltay), and one species of Gymnorhamphichthys. We suggest that the limited species richness of psammophilous fishes in forest streams along broad areas is related to the low complexity of this habitat, with few selective pressures favouring the fixation of evolutionary novelties. Nevertheless, historical factors contributing to a low Beta diversity among these stream habitats cannot be excluded.

Most of the Amazon basin drains across four structural units of the Brazilian relief: the Marginal Depression of the North Amazon, the Marginal Depression of the South Amazon, the Depression of the Occidental Amazon, and the Oriental Amazon Plateau (Ross, 2001). These structural units are mainly plain or slightly convex in low altitudes (the highest about $400 \mathrm{~m}$ a.s.1.). The huge sedimentary basin of the Amazon is widely coincident with the Depression of the Occidental Amazon and the Oriental Amazon Plateau, so-called Amazonian Lowlands (Ross, 2001; Goulding et al., 2003). This condition likely has played a major role in the origin and diversification of psammophilous fishes in South America. The exclusive occurrence of these fishes on sandy bottoms strongly indicates their dependence to this substrate type. As a consequence, the availability of this habitat was highly selective in the current distribution of these fishes throughout the South American river drainages. The flat terrains where most of the Amazon and Orinoco River basins drain have, consequently, a high tendency to deposition of sediments. The close relationship between this part of Amazon and Orinoco basins and freshwater fish psammophily is illustrated by the fact that northern South America supports the greatest species richness and diversity of sand-dwelling fishes. The psammophilous crenuchid clade (which includes $C$. cf. pteroides), the glanapterygine clade Pygidianops + Typhlobelus, and the heptapterids "Imparfinis" pristos, "Nannorhamdia" stictonotus, and Mastiglanis asopos, all are endemic to the Amazon and Orinoco basins, as well as rivers of the Guyana region (Buckup, 1993a, 2003; Bockmann \& Guazzelli, 2003; Schaefer et al., 2005). Thus, for these lineages psammophily arguably arose in northern South America. All members of the Imparfinis clade (which contains all psammophilous heptapterids) other than Imparfinis occur exclusively in the Amazon and Orinoco basins and Guiana drainages. Species of the genus Imparfinis (s.s.), which are very common in riffles and fast-flowing streams with rocky beds in South-eastern Brazil (Castro \& Casatti, 1997; Casatti \& Castro, 1998) are, as would be expected, rare in the Amazon basin. The psammophilous Rhamphichthyidae, which includes Gymnorhamphichthys rondoni, is also mostly known from northern South American drainages, mainly from the Amazon and Orinoco basins (Ferraris, 2003).

The only exception to the northern origin of psammophilous fishes is the trichomycterid Sarcoglanidinae, as the genus Microcambeva is endemic to the Brazilian south-eastern drainage (de Pinna \& Wosiacki, 2003; Costa et al., 2004). It is quite unlikely that the minute, delicate, and sedentary members of this subfamily dispersed across the orogenetic belt composed of Brazilian plateaus and highlands of the east and south-eastern Atlantic (Ross, 2001). Therefore, the earliest apparition of strict psammophily among freshwater fishes in South America possibly took place within the Trichomycteridae (Sarcoglanidinae) probably before the separation of the northern basins from the southern and south-eastern river drainages of South America.

According to Castro (1999) the only typical characteristic of freshwater stream-dwelling fishes in the Neotropical Region is the small size, with most species not surpassing 15 $\mathrm{cm}$, which is linked to paedomorphic traits (Weitzman \& Vari, 1988). This view is supported by the psammophilous assemblage here studied, whose paedomorphic traits appear to go further. This is probably the case of the scarce to totally absent pigmentation, small size, and large eyes. Some functional characteristics found among the studied psammophilous fishes, like the "drift-trap system" of Mastiglanis asopos, are due to a combination of plesiomorphic (thus not strictly designed to life in sandy bottoms) and apomorphic characters. Some autapomorphic characters are apparently designed to life in the sand, such as the osteological modifications of Stauroglanis gouldingi, "Imparfinis" pristos, and M. asopos, which converge to an acuminate snout. In sum, the life on and in sandy bottoms was accomplished by characters that appeared in distinct stages of the evolution of each group. The pre-existence of benthic habits, small size, and the broad distribution of rivers with sandy beds, mainly in the Amazon and Orinoco basins, possibly played a determinant role in the origin and diversification of psammophilous assemblages among freshwater fishes in South America.

\section{Acknowledgments}

We thank O. Pereira, O. F. Silva, and E. Venticinque for help in the field work; the Biological Dynamics of Forest Fragments Project (INPA/Smithsonian) for logistical and financial support at Fazenda Dimona; E. B. de Souza for initial identification of food items; J. Paulino for checking for oocyte occurrence; P. A. Buckup, R. Campos da Paz, M. R. de Carvalho, L. Casatti, F. C. T. Lima, M. C. C. de Pinna, R. E. dos Reis, and A. C. Ribeiro for sharing data and for suggestions on the manuscript. P. A. Buckup, B. Chernoff, J. Clayton, W. J. E. M. da Costa, S. L. Jewett, G. W. Nunan, O. T. Oyakawa, L. F. Palmer, L. R. Parenti, M. C. C. de Pinna, S. J. Raredon, M. A. Rogers, R. P. Vari, and M. Westneat allowed us to examine specimens under their care. This paper is part of the project "Sistemática, revisão taxonômica e biogeografia da tribo Heptapterini Gill, 1861 (Ostariophysi, Siluriformes, Heptapteridae)" (FAPESP 03/03108-5) and "All Catfish Species Inventory" Project (NSF DEB 0315963). Financial support from the CNPq and FAPESP is gratefully acknowledged by FAB and IS and from FAPEAM by JZ. Contribution 456 of the BDFF Project and contribution 02 of the Ygarapés Project. 


\section{Literature Cited}

Albert, J. S. 2001. Species diversity and phylogenetic systematics of American knifefishes (Gymnotiformes, Teleostei). Miscellaneous Publications, Museum of Zoology, University of Michigan, 190: 1-127.

Baskin, J. N. 1973. Structure and relationships of the Trichomycteridae. Unpublished Ph.D. Dissertation, City University of New York, New York. 389p.

Bernard, F. 1958. Plancton et benthos observées durant trois plongées en Bathyscaphe au large de Toulon. Annales du Institute Océanographique du Monaco (N. S.), 35(2): 287-326.

Bockmann, F. A. 1994. Description of Mastiglanis asopos, a new pimelodid catfish from northern Brazil, with comments on phylogenetic relationships inside the subfamily Rhamdiinae (Siluriformes: Pimelodidae). Proceeding of the Biological Society of Washington, 107(4): 760-777.

Bockmann, F. A. 1998. Análise filogenética da família Heptapteridae (Teleostei, Ostariophysi, Siluriformes) e redefinição de seus gêneros. Unpublished Doctoral Thesis, Universidade de São Paulo, São Paulo. 599p.

Bockmann, F. A. \& C. J. Ferraris, Jr. 2005. Systematics of the Neotropical catfish genera Nemuroglanis Eigenmann and Eigenmann 1889, Imparales Schultz 1944, and Medemichthys Dahl 1961 (Siluriformes: Heptapteridae). Copeia, 2005 (1): 124137.

Bockmann, F. A. \& G. M. Guazzelli. 2003. Family Heptapteridae (Heptapterids). Pp. 406-431. In: Reis, R. E., S. O. Kullander \& C. J. Ferraris, Jr. (Eds.). Check List of the Freshwater Fishes of South and Central America. Edipucrs, Porto Alegre, 729p.

Bockmann, F. A. \& I. Sazima. 2004. Trichomycterus maracaya, a new catfish from the upper rio Paraná, southeastern Brazil (Siluriformes: Trichomycteridae), with notes on the T. brasiliensis species-complex. Neotropical Ichthyology, 2 (2): 61-74.

Buckup, P. A. 1993a. Phylogenetic interrelationships and reductive evolution in Neotropical characidiin fishes (Characiformes, Ostariophysi). Cladistics, 9(3): 305-341.

Buckup, P. A. 1993b. Review of the characidiin fishes (Teleostei: Characiformes), with descriptions of four new genera and ten new species. Ichthyological Exploration of Freshwaters, 4 (2): 97-154.

Buckup, P. A. 2003. Family Crenuchidae (South American darters). Pp. 87-95. In: R. E. Reis, S. O. Kullander \& C. J. Ferraris, Jr. (Eds.). Check List of the Freshwater Fishes of South and Central America. Porto Alegre, Edipucrs, 729p.

Buckup, P. A. \& R. E. Reis. 1997. Characidiin genus Characidium (Teleostei, Characiformes) in southern Brazil, with description of three new species. Copeia, 1997(3): 531-548.

Burgess, W. E. 1989. An atlas of freshwater and marine catfishes. A preliminary survey of the Siluriformes. Neptune, Tropical Fish Hobbyist Publications, 783p.

Campos-da-Paz, R. 1997. Sistemática e taxonomia dos peixes elétricos das bacias dos Rio Paraguai, Paraná e São Francisco, com notas sobre espécies presentes em rios costeiros do leste do Brasil (Teleostei: Ostariophysi: Gymnotiformes). Unpublished Doctoral Thesis, Universidade de São Paulo, São Paulo. 336p.

Casatti, L. \& R. M. C. Castro. 1998. A fish community of the São Francisco River headwaters riffles, southeastern Brazil. Ichthyological Exploration of Freshwaters, 9 (3): 229-242.

Castro, R. M. C. 1999. Evolução da ictiofauna de riachos sul-americanos: padrões gerais e possíveis processos causais. Pp. 139155. In: Caramaschi, E. P., R. Mazzoni \& P. R. Peres-Neto (Eds.). Ecologia de peixes de riachos: estado atual e perspecti- vas. Oecologia Brasiliensis, 6, Rio de Janeiro, Ed. da Universidade Federal do Rio de Janeiro, 260p.

Castro, R. M. C. \& L. Casatti. 1997. The fish fauna from a small forest stream of the upper Paraná River basin, southeastern Brazil. Ichthyological Exploration of Freshwaters, 7(4): 337-352.

Costa, W. J. E. M. 1994. A new genus and species of Sarcoglanidinae (Siluriformes: Trichomycteridae) from the Araguaia basin, central Brazil, with notes on subfamilial phylogeny. Ichthyological Exploration of Freshwaters, 5(3): 207-216.

Costa, W. J. E. M. \& F. A. Bockmann. 1994a. A new genus and species of Sarcoglanidinae (Siluriformes: Trichomycteridae) from southeastern Brazil, with a re-examination of subfamilial phylogeny. Journal of Natural History, 28: 715-730.

Costa, W. J. E. M. \& F. A. Bockmann. 1994b. Typhlobelus macromycterus, a new blind glanapterygine fish (Siluriformes: Trichomycteridae) from the Rio Tocantins, Brazil. Tropical Zoology, 7: 67-72.

Costa, W. J. E. M., S. M. Q. Lima \& C. R. S. F. Bizerril. 2004. Microcambeva ribeirae sp. n. (Teleostei: Siluriformes: Trichomycteridae): a new sarcoglanidine catfish from the Rio Ribeira do Iguape basin, southeastern Brazil. Zootaxa, 563: 1-10.

Cozzi, J. \& E. Clark. 1995. Darting behavior of a sandburrower fish, Limnichthys nitidus (Creediidae) in the Red Sea. Environmental Biology of Fishes, 44(4): 327-336.

Ferraris, C. J., Jr. 1988. Relationships of the neotropical catfish genus Nemuroglanis, with a description of a new species (Osteichthys: Siluriformes: Pimelodidae). Proceedings of the Biological Society of Washington, 101(3): 509-516.

Ferraris, C. J., Jr. 2003. Family Rhamphichthyidae (Sand knifefishes). Pp. 492-493. In: Reis, R. E., S. O. Kullander \& C. J. Ferraris, Jr. (Eds.). Check List of the Freshwater Fishes of South and Central America. Edipucrs, Porto Alegre, 729p.

Fowler, H. W. 1940. Zoological results of the second Bolivian expedition for the Academy of Natural Sciences of Philadelphia, 1936-1937. Part I. The fishes. Proceedings of the Academy of Natural Sciences of Philadelphia, 92: 43-103.

Froese, R. \& D. Pauly (Eds.). 2005. FishBase. World Wide Web electronic publication. www.fishbase.org.

Goulding, M., R. Barthem \& E. Ferreira. 2003. The Smithsonian atlas of the Amazon. Smithsonian Books, Washington, 253p.

Greenberg, L. A. 1991. Habitat use and feeding behavior of thirteen species of benthic stream fishes. Environmental Biology of Fishes, 31(4): 389-401.

Helfman, G. S., B. B. Collette \& D. E. Facey. 1997. The diversity of fishes. Blackwell Science, Malden, 528p.

Hobson, E. S. \& J. R. Chess. 1986. Relationships among fishes and their prey in a nearshore sand community off southern California. Environmental Biology of Fishes, 17(3): 201-226.

Hori, M. 1983. Feeding ecology of thirteen species of Lamprologus (Teleostei; Cichlidae) coexisting at a rocky shore of Lake Tanganyika. Physiology \& Ecology Japan, 20(2): 129-149.

Horn, M. H., K. L. M. Martin \& M. A. Kotchowski (Eds.). 1999. Intertidal fishes: life in two worlds. Academic Press, San Diego, $399 \mathrm{p}$.

Hyslop, E. J. 1980. Stomach contents analysis: a review of methods and their application. Journal of Fish Biology, 100: 411-429.

Kobayagawa, M. 1991. The world of catfishes. Tropical Fish Hobbyist Publications, Neptune, 192p.

Landim, M. I. P. F. \& W. J. E. M. Costa. 2002. Listrura tetraradiata (Siluriformes: Trichomycteridae): a new glanapterygine catfish from the southeastern Brazilian coastal plains. Copeia, 2002(1): $152-156$ 
Le Bail, P.-Y., P. Keith \& P. Planquette. 2000. Atlas des poissons d'eau douce de Guyane. Collection Patrimoines Naturels, 43(II), fascicule II, MNHN/SPN, 307p.

Lehner, P. N. 1979. Handbook of ethological methods. Garland STPM Press, New York, 403p.

Lowe-McConnell, R. H. 1987. Ecological studies in tropical communities. Cambridge University Press, Cambridge, 382p.

Lowe-McConnell, R. H. 1991. Natural history of fishes in Araguaia and Xingu Amazonian tributaries, Serra do Roncador, Mato Grosso, Brazil. Ichthyological Exploration of Freshwaters, 2(1): 63-82.

Lundberg, J. G., A. H. Bornbusch \& F. Mago-Leccia. 1991. Gladioglanis conquistador n. sp., from Ecuador with diagnoses of the subfamilies Rhamdiinae Bleeker and Pseudopimelodinae n. subf. (Siluriformes, Pimelodidae). Copeia, 1991(1): 190-209.

Mees, G. F. \& P. Cala. 1989. Two new species of Imparfinis from northern South America (Pisces, Nematognathi, Pimelodidae). Proceedings of the Koninklijke Nederlandse Akademie van Wetenschappen, Ser. C, 92(3): 379-394.

Myers, G. S. 1944. Two extraordinary new blind nematognath fishes from the rio Negro, representing a new subfamily of Pygidiidae, with a rearrangement of the genera of the family, and illustrations of some previously described genera and species from Venezuela and Brazil. Proceedings of the California Academy of Sciences (Ser. 4), 23(40): 591-602.

Myers, G. S. \& S. H. Weitzman. 1966. Two remarkable new trichomycterid catfishes from the Amazon Basin in Brazil and Colombia. Journal of Zoology, London, 149: 277-287.

Nanjappa, P., L. Brand \& M. J. Lannoo. 2000. Swimming patterns associated with foraging in phylogenetically and ecologically diverse American weakly electric teleosts (Gymnotiformes). Environmental Biology of Fishes, 58(2): 97-104.

de Pinna, M. C. C. 1989a. A new sarcoglanidine catfish, phylogeny of its subfamily, and appraisal of the phyletic status of the Trichomycterinae. American Museum Novitates, 2950: 1-39.

de Pinna, M. C. C. 1989b. Redescription of Glanapteryx anguilla, with notes on the phylogeny of Glanapteryginae (Siluriformes, Trichomycteridae). Proceedings of the Academy of Natural Sciences of Philadelphia, 141: 361-374.

de Pinna, M. C. C. 1992. A new subfamily of Trichomycteridae (Teleostei, Siluriformes), lower loricarioid relationships and a discussion on the impact of additional taxa for phylogenetic analysis. Zoological Journal of the Linnean Society, 106(3): 175-229.

de Pinna, M. C. C. 1998. Phylogenetic relationships of Neotropical Siluriformes (Teleostei: Ostariophysi): historical overview and synthesis of hypotheses. Pp. 279-330. In: Malabarba, L. R., R. E. Reis, R. P. Vari, Z. M. S. Lucena \& C. A. S. Lucena (Eds.). Phylogeny and classification of Neotropical fishes. Edipucrs, Porto Alegre, 729p.

de Pinna, M. C. C. \& W. C. Starnes. 1990. A new genus and species of Sarcoglanidinae from the Río Mamoré, Amazon Basin, with comments on subfamilial phylogeny (Teleostei, Trichomycteridae). Journal of Zoology, 222: 75-88.

de Pinna, M. C. C. \& K. O. Winemiller. 2000. A new species of Ammoglanis (Siluriformes: Trichomycteridae) from Venezuela. Ichthyological Explorations of Freshwaters, 11(3): 255-264.

de Pinna, M. C. C. \& W. B. Wosiacki. 2003. Family Trichomycteridae (Pencil or parasitic catfishes). Pp. 270-290. In: Reis, R. E., S. O. Kullander \& C. J. Ferraris, Jr. (Eds.). Check List of the Freshwater Fishes of South and Central America. Edipucrs, Porto Alegre, 729p.
Roberts, T. R. \& D. J. Stewart. 1976. An ecological and systematic survey of fishes in the rapids of the lower Zaïre or Congo River. Bulletin of the Museum of Comparative Zoology, 147(6): 239317.

Ross, J. L. S. 2001. Os fundamentos da geografia da natureza. Pp. 13-65. In: Ross, J. L. S. (Org.). Geografia do Brasil. 4th Ed. São Paulo, EDUSP, 552p.

Sabino, J. \& J. Zuanon. 1998. A stream fish assemblage in Central Amazonia: distribution, activity patterns and feeding behavior. Ichthyological Exploration of Freshwaters, 8(3): 201-210.

Sazima, I. 1980. Behavior of two Brazilian species of parodontid fishes, Apareiodon piracicabae and A. ibitiensis. Copeia, 1980(1): 166-169.

Schaefer, S. A., F. Provenzano, M. de Pinna \& J. N. Baskin. 2005. New and noteworthy Venezuelan Glanapterygine catfishes (Siluriformes, Trichomycteridae), with discussion of their biogeography and psammophily. American Museum Novitates, 3496: 1-27.

Schwassmann, H. O. 1976. Ecology and taxonomic status of different geographic populations of Gymnorhamphichthys hypostomus Ellis (Pisces, Cypriniformes, Gymnotoidei). Biotropica, 8(1): 25-40.

Schultz, L. P. 1944. The catfishes of Venezuela, with description of thirty-eight new forms. Proceedings of the United States National Museum, 94(3172): 173-338.

Stewart, D. J. 1985. A new species of Cetopsorhamdia (Pisces: Pimelodidae) from the Río Napo basin of eastern Ecuador. Copeia, 1985(2): 339-344.

Stewart, D. J. 1986. A new pimelodid catfish from the deep-river channel of the Rio Napo, eastern Ecuador (Pisces: Pimelodidae). Proceedings of the Academy of Natural Sciences of Philadelphia, 138(1): 46-52.

Sulak, K.J., 1984. Chlorophthalmidae. Pp. 412-420. In: Whitehead, P. J. P., M.-L. Bauchot, J.-C. Hureau, J. Nielsen \& E. Tortonese (Eds.). Fishes of the north-eastern Atlantic and the Mediterranean. UNESCO, Paris, 1473p.

Taylor, W. R. \& G. C. Van Dyke. 1985. Revised procedures for staining and clearing small fishes and other vertebrates for bone and cartilage study. Cybium, 9(2): 107-119.

Trajano, E. 1990. The agonistic behaviour of Pimelodella kronei, a troglobitic catfish from Southeastern Brazil (Siluriformes, Pimelodidae). Behavioral Processes, 23(3): 113-124.

Weitzman, S. H. \& R. P. Vari. 1988. Miniaturization in South American freshwater fishes; an overview and discussion. Proceedings of the Biological Society of Washington, 101(2): 444-465.

Zuanon, J. \& I. Sazima. 2004. Natural history of Stauroglanis gouldingi (Siluriformes: Trichomycteridae), a miniature sanddwelling candiru from central Amazonia streamlets. Ichthyological Exploration of Freshwaters, 15(3): 201-208.

Received June 2005 Accepted February 2006 